\title{
Critical Success Factors on the Implementation of ERP Systems: Building a Theoretical Framework
}

\author{
Asimina Kouriati ${ }^{1}$ \\ PhD Candidate, Department of Agricultural Economics \\ Aristotle University of Thessaloniki (AUTH) \\ Greece, Thessaloniki
}

\author{
Thomas Bournaris ${ }^{2}$ \\ Assistant Professor, Department of Agricultural Economics \\ Aristotle University of Thessaloniki (AUTH) \\ Greece, Thessaloniki
}

\author{
Basil Manos ${ }^{3}$ \\ Em. Professor, Department of Agricultural Economics \\ Aristotle University of Thessaloniki (AUTH) \\ Greece, Thessaloniki
}

\author{
Stefanos A. Nastis ${ }^{4}$ \\ Associate Professor, Department of Agricultural Economics \\ Aristotle University of Thessaloniki (AUTH) \\ Greece, Thessaloniki
}

\begin{abstract}
Existing pressure for the confrontation of a radically changing external environment has led many companies to invest in various Information Systems, such as Enterprise Resource Planning (ERP), in order to optimize their production processes and strategies. Despite the fact that ERP system is an important strategic tool, many companies fail to take advantage of its benefits due to their default in many aspects of management and implementation. This study aims to investigate the critical success factors of enterprise resource planning system implementation and build a categorization framework so as to create a theoretical base that enhances any further research approaches in various sectors of the economy. Therefore, 37 ERP critical success factors were identified by using Content Analysis method and classified into relative categories to the ERP orientations of implementation and the ERP life cycle phases. Finally, these two types of categorization were merged in order to examine the critical success factors' behavior during the ERP implementation. This paper and the multilateral theoretical framework it creates, sets out how critical success factors must be taken into account by companies and marks a beginning point that promises a sequence of further research approaches in particular economic sectors or in a set of them. By fulfilling the purpose of this study, a significant contribution to computer science literature and especially to the ERP field is offered.
\end{abstract}

Keywords-Enterprise resource planning (ERP); ERP implementation; critical success factors (CSFs); content analysis (CA); categorization; theoretical framework

\section{INTRODUCTION}

Competitiveness and globalization have caused radical changes in the business environment [1] something that led many companies to rely on various Information Systems, such as Enterprise Resource Planning (ERP) [2, 3] in order to optimize their production processes and strategies. Enterprise resource planning (ERP) software is a solution that help various companies to integrate all the business functions [4] using shared information and a common database [5]. In particular, [6] argue that ERP uses a central database that collects and organizes data in real time in order to achieve this integration between business operating domains. Additionally,
ERP system leads to the acquisition of many business advantages, such as operational efficiency and effectiveness, easy access to reliable information, maintenance of the competitive advantage, reduce the complexity of processes, profit increase and reduce cost [4, 5, 7-12]. In addition to its wide range of practical applications, ERP system is an equally active area of research interest [13]. Researches about ERP concern: the general frame of literature, the software and its optimization, the identification of factors that contribute to the adoption and the selection of those systems, the advantages and disadvantages of ERP implementation and finally, the efficiency estimation of ERP implementation [11, 13-19]. The identification of factors that are adjudged critical in ERP implementation success [9, 20 etc.] is also considered as an interesting research project.

Although many companies enjoy the benefits that ERP provides, other companies face various challenges regarding the implementation of these systems [4, 21] such as financial failures [8]. This happens because companies fail to take advantage of ERP benefits due to their default in some views of management and implementation [11]. The author in [22], in an annual report, states that $42 \%$ of the responders deem ERP implementation as successful. This is an important decline compared with the $82 \%$ positive responders of the previous year [23]. It is also mentioned in literature that ERP implementation failure starts from the wrong choice of ERP software, which is its initial state [17]. What is more, the unsuccessful implementation may be caused by organizational change, wrong organizational politics, inefficient project management, incorrect understanding of the system, incompatibility with business processes, poor management support and user education as well [13, 24]. These facts led many researchers to investigate factors that contribute to the successful implementation of ERP system in order to inform managers about the risk of adopting an ERP system and supply them with the necessary managing tools. Also, a corresponding paper that identifies the critical success factors in detail and quotes them as a background for further research approaches has not been done in the past. 
The above reasons led this paper to investigate the critical success factors and classify them into categories relative to the ERP (orientations of) implementation and the ERP life cycle phases. CSFs' investigation and categorization, based on a literature survey, build a theoretical framework for further research approach in various economic fields which is the principal aim of this study. By fulfilling this aim, this paper offers a significant contribution to computer science literature and especially to the ERP field. At this point, it should be mentioned that this paper has the following structure: 1) a literature review of previous studies about the identification of critical success factors and their categorization; 2) the examination of the theory of content analysis; 3) the identification of critical success factors that was achieved by implementing the content analysis method; 4) the factors which were classified into two types of categorization and were merged with each other; 5) the conclusions that are drawn about the present study's content, 6) present study's practical implication and originality, 7) proposals for further research approaches and 8) research limitations.

\section{LITERATURE REVIEW}

Successful implementation of ERP systems often requires the identification of critical factors [7]. Apart from the CSFs' identification, researchers use also the categorization method because makes CSFs' searches easier by assigning concepts to the categories and defining the relationships between them [25].

\section{A. Critical Success Factors of ERP Implementation}

The elements that have a significant impact on the success of an ERP system are known as Critical Success Factors (CSFs) [26]. CSFs terminology appeared during 60s' to help many companies to achieve their goals and embrace competitiveness [5, 27, 28]. In an ERP environment, CSFs are defined as a sum of activities [29] that contribute to the creation of a mechanism for providing the information needed to the companies' managers [30].

\section{B. Critical Success Factors' Identification}

Many researches focused on the ERP systems' failure [4, 31] which can significantly be reduced by adopting a CSFs' strategic analysis [27, 32]. The identification and understanding of CSFs help a company to take effective measures in order to eliminate the reasons that affect the ERP systems' implementation in a negative way [33, 34]. The author in [7] claimed that the successful implementation of ERP systems often requires the identification of critical factors. This is proven by the fact that CSFs given in the literature are many. The current literature contains numerous researches about the critical success factors' identification [1, $5,7,35-37]$ which is claimed that it started from the moment that ERP system appeared in companies [20].

\section{Critical Success Factors’ Categorization}

Apart from the CSFs' identification, researchers use also the categorization method - or else taxonomy into categoriesin order to find out associated concepts for each CSF [25]. A taxonomy analysis matters because helps researchers to organize their knowledge issues surrounding the ERP implementation problems [25]. Categorization of critical factors also highlights the key features of ERP systems based on business process management principles [29] and is widely used in the literature [28, 32, 38, 39].

\section{Identification and Categorization of Critical Success Factors: Previous Studies Relevant Content}

Some researches with a relevant content is this of [40], who reviewed literature and identified twelve CSFs which were categorized them into strategic and tactical. The author in [41], identified ten factors creating, in this way, a base for a further research in Chinese companies and classified them into ERP implementation relative categories. The author in [29] identified twelve factors and provided a comprehensive taxonomy by dividing them into three parts corresponding to the ERP implementation's characteristics, such as setting-up, deployment and evaluation. Based on the relevant literature and an information system research model, critical factors that influence the ERP implementation success were identified in the research of [38]. These factors were classified also into four environmental categories in order to develop a theoretical framework which examines the relationship between CSFs and ERP implementation success in companies which belong to the Chinese economy [38]. The author in [39] examined 45 articles, identified 26 CSFs by using the content analysis method and divided them into strategic and tactical. After analyzing 95 studies by the methods of content and frequency analysis, [25] suggested 17 CSFs and, subsequently, classified them into ERP implementation categories.

The author in [32], after a literature survey, identified 33 critical success factors related to the implementation of ERP systems and, then, classified them from an operational and organizational point of view. The author in [5] identified nine critical success factors and studied their significance within Greek small and medium-sized enterprises. A literature review, in which 20 CSF were identified, was conducted by [28]. Then, these factors were grouped into organizational, project, users, expertise and software categories. This initial analysis was carried out in order to conduct a further investigation about ERP CSFs' importance in educational institutions [28]. The author in [37] identified 20 CSFs of ERP implementation in higher education by using the content analysis method of 38 studies in total. The author in [42] investigated the ERP critical success factors using the literature and investigated their relationship with the ERP success in the Indian automotive industry. Study of [43] examined the critical success factors on the implementation of ERP systems in some companies in the United Arab Emirates. A review of the relevant literature was held in order to identify some CSFs that have the power to exert a great impact on the success -or not- of the ERP implementation in general. Thereafter, the study conducted a further investigation into the effects of those CSFs on the implementation processes of ERP systems in a number of organizations within the United Arab Emirates.

As it can be perceivable, conducting only a literature review is not sufficient for the analysis of existing literature studied. Therefore, researchers impose further investigation by using specially designed questionnaires in order to specify the critical factors that strongly affect the successful ERP system 
implementation in particular economic sectors or in a set of them $[5,9,28$, etc. $]$. As mentioned in the introductory section, this study restricts only on the first part aiming to create a multilateral theoretical framework that will be used by researchers for further investigation in various economic sectors. The ways in which this theoretical framework can be exploited are presented through the presentation of proposals for further studies at the end of this paper.

\section{CONTENT ANALYSIS (CA)}

Content Analysis (CA) is also widely used by researchers in the fields of critical success factors and ERP implementation in order to identify these factors by grouping them according to their common meaning and purpose [25, 37, 39, 44] and by accomplishing this way their general mapping [12]. This method, is the most common text analysis technique that constitutes a research tool for concept identification within a set of texts [45].

\section{A. Content Analysis as a Research Methodology}

Content analysis is a method that was initially developed for the human communication analysis in the field of social sciences but various empirical information systems' studies, adopted this method as part of research methodology [46]. This method is used to describe systematically, objectively and quantitatively a 'communication' material for the identification of the required characteristics of content. Also, qualitative research method, concerns the quantification of qualitative data and is widely used. In addition to that, it is applied to various media of "communication" through the study of documents and media (books, articles, journals, webpages, letters and interviews) [46-48]. In this case, the media of "communication" are the scientific publications of the relevant literature [46]. CA method concerns the shrinkage of textual data by following a set of specific codes [49] or else it can be seen as a technique that 'squeezes' the words of a text into fewer categories based on certain coding rules. Coding is a part of the analysis that concerns the designation and categorization of phenomena and, during this procedure, data are separated into meaning parts, are carefully examined and compared to similarities and differences [39, 50]. These facts help researchers to study many data via a systematic methodology. CA is a method of summarizing any form by measuring its various aspects [51] and focuses on how often words or meanings appear in texts. This approach has been used occasionally to address a variety of issues and its basic idea is to obtain a list of concepts so as to measure the occurrence times of each concept in each text [39, 51].

\section{B. Content Analysis Principles}

There is a large number of choices that researchers have to make when implementing the content analysis method. These choices define the application of this research method and, also, influence the obtained results, the interpretation and the automation of the coding process [51]. The author in [51] proposed eight stages of choices that have to be made when a researcher wants to apply the content analysis method. These stages are presented below $[39,51]$ :

1) Selecting analysis level - What do the concepts mean: This stage refers to the selection of the research method. That is, if a single word or a set of words or phrases is searched, the research method is selected. This reason why this happens is that different results are going to be obtained when individual words are used during the research, in contrast to those of whole sentences. The use of individual words is helpful if the researcher wants to compare and contrast the results in specific terms. On the other hand, the use of whole phrases is helpful if the researcher wants to capture general concepts in a particular socio-linguistic community [51]. This paper uses different word combinations and whole phrases in order to find specific articles that are relevant to the critical factors of successful ERP implementation.

2) Select the number of concepts to be coded: This stage involves the choice of encoding a predefined set (number) of concepts or a more generalized and inductive coding approach $[39,51]$. An interactive and inductive approach is selected to be used as part of this analysis because it allows the integration of the most recognized critical success factors of ERP implementation [39].

3) Choosing to code the frequency of a concept or its existence: This stage concerns the choice of measuring the relevant concepts or the situation that is implied around a phenomenon. The author in [51], more specifically, argued that the study of a whole phenomenon simplifies the process and eliminates the frequency correlations due to editorial selection. In the present study, it was initially chosen to emphasize on the frequency of concepts in order to construct an initial model of critical factors by taking into account the situation indicated around them according to their meaning [39].

4) The distinction of concepts - Level of generalization: A researcher must choose whether particular concepts should be coded exactly as recorded the same even they appear in various forms [51]. In other words, any word in this research that implies the same meaning is categorized with the same structure. As mentioned above, emphasis is initially laid on the frequency of the concepts. Only in this way will the first identification of the factors be achieved. In the second stage, a review of the factors meaning is done in order to redefine the factors and reduce them. These choices were made to facilitate the further research process.

5) Creating rules for coding texts: To ensure cohesion and coherence in coding, it is necessary to establish a set of "translation" rules that can be applied throughout the coding process [39]. In order to generalize the concepts of the texts systematically, the creation of a set of rules that translate general concepts into more general ones is required [51]. These rules can be adapted under the guidance of the literature as it can be noticed below:

- The articles involved in the content analysis highlight the critical success factors. Essentially, the collection of factors is limited only to those cited by the researchers as key and critical. 
- Each one of the factors is recorded in a bibliographic program where their meaning is listed based on the selected research material of the analysis.

- Then, according to the factors nominal similarity, the reference frequency is measured.

- After that, the meaning of these factors is studied, in order to redefine their conceptual similarity, and the reference frequency is recounted.

- When the factors are fully identified, conceptually relevant categories and categories related to the life stages of the system will be created.

- Once the categories are completed, factors will be classified according to the categories established.

6) Management of "useless" information: This stage determines how the researcher should deal with the unnecessary information. The author in [51] was wondering whether "useless" information should be deleted, omitted or be used to re-evaluate and modify the coding system [51]. Deletion simplifies the process by minimizing the cost of editing and creates a simplified text which is manageable easily [51]. The author in [39] supported that projects, which refer to the investigation of the critical factors of successful ERP implementation, focus on the aggregation of all concepts regarding success factors. This is the reason why this research method includes the entire content of the literature articles. However, the merge of critical factors that have similar meaning is selected.

7) Text coding - What happens in the case of implied content: The author in [51], was wondering if the media of communication are coded as well as what concepts are present or/and what concepts are implied. Only if explicit concepts are used when coding, then texts can be compared in their writing style and a fully automated procedure can be followed [51]. On the contrary, the use of implicit concepts allows the researcher to compare texts from the point of view of social knowledge. This process is of vital significance to the meaning level where each term is coded [51]. In this case, the meaning of all factors is always examined in the light of the articles of analysis.

8) Analysis of results: The actual analysis stage is the examination of the frequency results [39]. In the present study, the researcher tries to seek a conclusion by examining the results and trends with regard to the critical success factors on ERP implementation. Using content analysis method, the critical factors of ERP successful implementation were extracted first, and, then, they were categorized. In this way, the main objective of this paper is covered by creating a theoretical framework that could form the basis for a further research approach in particular economic sectors or in a set of them.

\section{CRITICAL SUCCESS FACTORS’ IDENTIFICATION THROUGH CONTENT ANALYSIS (CA) METHOD APPLICATION}

As it was mentioned earlier, content analysis method implementation concerns the quantification of qualitative data and is applied to various media of "communication" through the study of documents and media [46-48]. In this study, the media of "communication" are the scientific publications of the relevant literature [46].

\section{A. Used Keawords in the Analysis}

The selection of the literature material used came after searching in Google Scholar, Scopus and Research Gate and it was instrumental in shaping the main objective of this study. During this research, various keyword combinations were used in order to make the literature material solely relevant to the CSFs as defined in the first rule of analysis. The keywords that were used during this research are listed below (Table I).

Reviewing the literature [5, 24, 32, 37, 39, 52], the repeated use of some studies in similar research applications was observed [25, 29, 35,40]. This fact had been taken into account when the research material of the analysis was chosen because the literature itself indicates the trends in the identification of ERP critical success factors.

\section{B. Distribution of the Analysis' Selected Research Material}

The research material is considered important for the development of a factor list that influences the successful implementation [46] and belongs to the current literature as well as the older one, as in the case of other researchers [46, 37, 39]. Specifically, fifty research papers, fifteen conference papers and two dissertations were selected for the application of this analysis given that they met specific requirements, such as their relationship with the present research topic, the origin from reliable resources (scientific journals, conference proceedings, university and academic portals) and the year of publication (over 1999) [26, 39, 46] which is significant because the analysis refers to last two decades. The research material below is presented according to the way journals, conference proceedings and dissertations are distributed annually [27, 44] (Table II).

The annual distribution of journals, proceedings, and theses is presented in the above table in terms of sums. These sums are also converted to percentages per year (\%) via the use of the rule of three. Twelve studies (17.91\%) belong to 2018, eight studies (11.94\%) to 2017, seven studies to 2014 (10.45\%), five studies to 2015 (7.46\%), four studies $(6.97 \%)$ to 2003, 2005, 2010 and 2013, three studies to 2007 and 2011 (4.48\%), two studies (2.99\%) to 2006 and 2009 and one study $(1.49 \%)$ to each of the remaining years. As it can be seen below, the material of 2018 outweighs the rest of the other years (Fig. 1).

\section{Research Material Sectors}

After the research on material collection, an initial review was carried out in order to examine the sectors in which critical factors of ERP successful implementation were investigated. The selected research material, which the corresponding research approach is applied to, focuses on various business sectors. These sectors were divided into those of the general business field, SMEs, industry, education, logistics, public, retail, processing of agricultural products, trade of consumer goods, and banking (Table III). 
TABLE I. USED KEYWORDS

\begin{tabular}{|c|c|c|c|}
\hline Id & Keywords & Id & Keywords \\
\hline 1 & Critical Factors + Enterprise Resource Planning & 21 & ERP + Successful Implementation \\
\hline 2 & Critical Factors + Enterprise Resource Planning + Implementation Success & 22 & Factors + ERP + Implementation Success \\
\hline 3 & Critical Factors + Enterprise Resource Planning + Success & 23 & $\begin{array}{l}\text { Key Factors + Enterprise Resource Planning + Implementation } \\
\text { Success }\end{array}$ \\
\hline 4 & $\begin{array}{l}\text { Critical Factors + Enterprise Resource Planning + Successful } \\
\text { Implementation }\end{array}$ & 24 & Key Factors + Enterprise Resource Planning + Success \\
\hline 5 & Critical Factors + Enterprise Systems + Implementation Success & 25 & $\begin{array}{l}\text { Key Factors + Enterprise Resource Planning + Successful } \\
\text { Implementation }\end{array}$ \\
\hline 6 & Critical Factors + Enterprise Systems + Success & 26 & Key Factors + Enterprise Systems + Implementation Success \\
\hline 7 & Critical Factors + ERP + Successful Implementation & 27 & Key Factors + Enterprise Systems + Success \\
\hline 8 & Critical Factors + Successful + Enterprise Resource Planning & 28 & Key Factors + ERP + Implementation \\
\hline 9 & $\begin{array}{l}\text { Critical Factors + Successful + Enterprise Resource Planning + } \\
\text { Implementation }\end{array}$ & 29 & Key Factors + ERP + Implementation Success \\
\hline 10 & Critical Success Factors + Enterprise Resource Planning + Implementation & 30 & Key Factors + Successful Implementation \\
\hline 11 & Critical Success Factors + Enterprise Resource Planning & 31 & Key Success Factors + Enterprise Resource Planning \\
\hline 12 & Critical Success Factors + Enterprise Systems + Implementation & 32 & $\begin{array}{l}\text { Key Success Factors + Enterprise Resource Planning + } \\
\text { Implementation }\end{array}$ \\
\hline 13 & Critical Success Factors + ERP + Implementation & 33 & Key Success Factors + Enterprise Systems + Implementation \\
\hline 14 & CSFs + Enterprise Resource Planning + Implementation & 34 & Key Success Factors + ERP \\
\hline 15 & CSFs + Enterprise Systems + Implementation & 35 & Key Success Factors + ERP + Implementation \\
\hline 16 & CSFs + ERP & 36 & Successful + Enterprise Resource Planning + Implementation \\
\hline 17 & CSFs + ERP + Implementation & 37 & Successful + ERP \\
\hline 18 & Enterprise Resource Planning + Implementation Success & 38 & Successful + ERP + Implementation \\
\hline 19 & Enterprise Resource Planning + Successful Implementation & 39 & Enterprise Systems + Implementation Success \\
\hline 20 & ERP + Implementation Success & 40 & Enterprise Systems + Successful Implementation \\
\hline
\end{tabular}

TABLE II. ANNUAL DistRIBUTION OF THE ANALYSIS’ SELECTED RESEARCH MATERIAL

\begin{tabular}{|c|c|c|c|c|c|c|c|c|}
\hline Type of Study & 1999 & 2000 & 2001 & 2002 & 2003 & 2004 & 2005 & 2006 \\
\hline Journal Papers & 0 & 0 & 1 & 0 & 2 & 1 & 3 & 2 \\
\hline Proceedings Papers & 1 & 1 & 0 & 1 & 2 & 0 & 1 & 0 \\
\hline Theses & 0 & 0 & 0 & 0 & 0 & 0 & 0 & 0 \\
\hline Sum & 1 & 1 & 1 & 1 & 4 & 1 & 4 & 2 \\
\hline$\%$ & 1.5 & 1.5 & 1.5 & 1.5 & 6 & 1.5 & 6 & 3 \\
\hline Type of Study & 2007 & 2008 & 2009 & 2010 & 2011 & 2012 & 2013 & 2014 \\
\hline Journal Papers & 2 & 0 & 2 & 4 & 3 & 0 & 4 & 4 \\
\hline Proceedings Papers & 1 & 1 & 0 & 0 & 0 & 1 & 0 & 3 \\
\hline Theses & 0 & 0 & 0 & 0 & 0 & 0 & 0 & 0 \\
\hline Sum & 3 & 1 & 2 & 4 & 3 & 1 & 4 & 7 \\
\hline$\%$ & 4.5 & 1.5 & 3 & 4.5 & 5 & 1.5 & 6 & 10.5 \\
\hline Type of Study & 2015 & 2016 & 2017 & 2018 & 2019 & Sum & $\%$ & \\
\hline Journal Papers & 4 & 0 & 7 & 10 & 1 & 50 & 74,62 & \\
\hline Proceedings Papers & 1 & 1 & 0 & 1 & 0 & 15 & 22,38 & \\
\hline Theses & 0 & 0 & 1 & 1 & 0 & 2 & 2,98 & \\
\hline Sum & 5 & 1 & 8 & 12 & 1 & 67 & - & \\
\hline$\%$ & 7.5 & 1.5 & 12 & 18 & 1.5 & - & 100 & \\
\hline
\end{tabular}




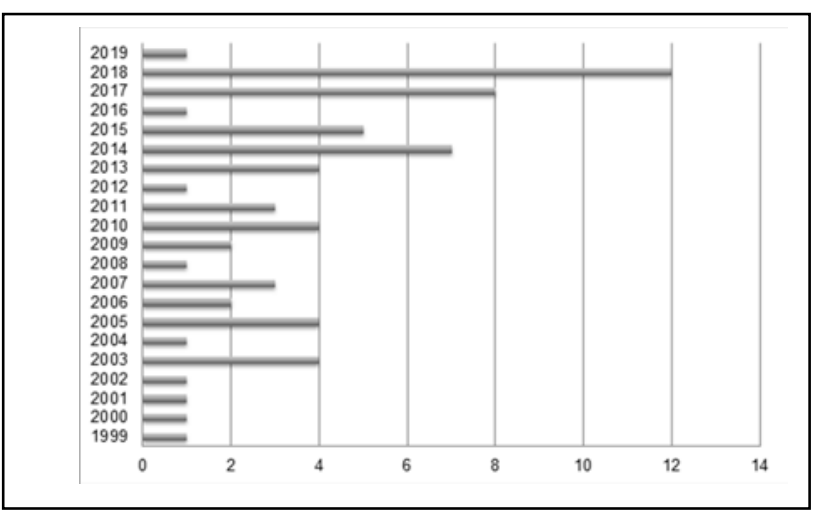

Fig. 1. Annual Distribution of the Selected Research Material.

TABLE III. ECONOMIC SECTORS IN WHICH THE SELECTED RESEARCH MATERIAL FOCUSES

\begin{tabular}{|l|l|l|l|l|}
\hline Id & Economic Sector & Studies & Sum & $\mathbf{( \% )}$ \\
\hline 1 & $\begin{array}{l}\text { General Field of } \\
\text { economic sectors }\end{array}$ & $\begin{array}{l}{[1,25,27,29,35,38-} \\
41,53-72]\end{array}$ & $\mathbf{2 9}$ & $\mathbf{4 3 . 3}$ \\
\hline 2 & SMEs & {$[5,8-10,32,73-80]$} & $\mathbf{1 3}$ & $\mathbf{1 9 . 4}$ \\
\hline 3 & Industry & {$[7,20,42,52,81-85]$} & $\mathbf{9}$ & $\mathbf{1 3 . 4}$ \\
\hline 4 & Education & {$[24,28,36,37,86,87]$} & $\mathbf{6}$ & $\mathbf{8 . 9 6}$ \\
\hline 5 & Logistics & {$[88,89]$} & $\mathbf{2}$ & $\mathbf{2 . 9 9}$ \\
\hline 6 & Public Sector & {$[12,90,91]$} & $\mathbf{3}$ & $\mathbf{4 . 4 8}$ \\
\hline 7 & $\begin{array}{l}\text { Processing of } \\
\text { agricultural products }\end{array}$ & {$[21,34]$} & $\mathbf{2}$ & $\mathbf{2 . 9 9}$ \\
\hline 8 & Retail & {$[92]$} & $\mathbf{1}$ & $\mathbf{1 . 4 9}$ \\
\hline 9 & Consumer goods & {$[93]$} & $\mathbf{1}$ & $\mathbf{1 . 4 9}$ \\
\hline 10 & Banking & {$[94]$} & $\mathbf{1}$ & $\mathbf{1 . 4 9}$ \\
\hline Sum & & & $\mathbf{6 7}$ & $\mathbf{1 0 0}$ \\
\hline
\end{tabular}

Studies focused on the general investigation of CSFs in various companies - or without precise business activity belong to the general field. In this case, there are 29 (43.3\%) corresponding studies. In the case of small and medium-sized enterprises, there are $13(19.4 \%)$ studies. These studies are equally relevant to the general field's studies. However, it is considered that there should be in a separate category because there are several research applications in the literature that emphasize the size of companies. The research applications of the industry sector are 9 (13.43\%) and refer to the automotive, fire protection, manufacturing, electronics and construction companies. Education field studies, that are included in the analysis, are $6(8.96 \%)$. Also, there are 3 studies (4.48\%) that are specialized in the public sector. Two studies (2.99\%) correspond to the field of processing agricultural products and logistics. Finally, one study (1\%) corresponds in each field of the following sectors: retail, trade of consumer goods and banking. The deviations per economic sector are illustrated in the next chart (Fig. 2).

This chart shows that the general business field studies outperform the other sectors' studies. Assuming that the corresponding research applications in these sectors exist also in the actual range of the literature, it could be concluded that the majority of the whole literature surveys do not focus on a specific business activity, but they address the issue of ERP critical success factors in general.

\section{Collection of Critical Success Factors}

Moreover, a further review was carried out in order to collect the CSFs. Each of the factors and their meanings was recorded in a bibliographic program (Excel program) according to the selected research material. At first, 1069 factors were collected by measuring their appearance one to one. With regard to their nominal identity, critical success factors were decreased to 48. Regarding the rules of content analysis, factors' meaning was reviewed in order to redefine the conceptual similarity and in this way factors were reduced to 37. In the next table, the meaning of the identified critical success factors on ERP implementation is presented. The meanings resulted from reviewing the studies of the selected research material [5, 7, 20, 25, 28, 60 etc.] (Table IV).

In listing the meaning of critical success factors the characteristics that should be taken into account by entrepreneurs in order to successfully implement ERP systems are also essentially identified. The critical success factors' frequency order is presented in the following table in quantitative and percentage terms which are calculated via the rule of three (Table V).

Examining the frequency values, as they resulted from the content analysis's application (by measuring their appearance one to one), it could be considered that the reference level of the CSFs in the selected research material maybe reflects a real situation of the relevant literature in which emphasis is initially placed on top management (provision of the necessary resources for the operation of the system) and, subsequently, on various organizational and financial characteristics. Also, it could be concluded that the literature emphasis lies on the factors that have not been mentioned in detail in it except from some researchers who have considered them worthy of study, such as the number of implemented modules, company-wide support and commitment and knowledge management.

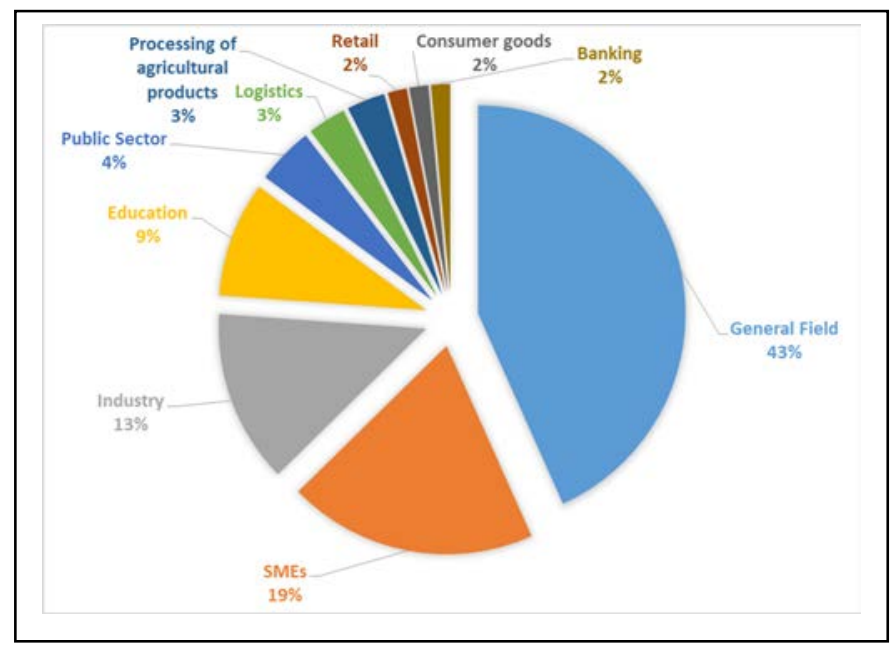

Fig. 2. Deviations' Structure Diagram of the Examined Economic Sectors. 
TABLE IV. MEANING OF IDENTIFIED CRITICAL SUCCESS FACTORS

\begin{tabular}{|c|c|}
\hline CSFs & Meaning of CSFs \\
\hline $\begin{array}{l}\text { Top management support and } \\
\text { commitment }\end{array}$ & $\begin{array}{l}\text { Level of commitment and support in obtaining ERP and providing valuable resources (system payments, selection } \\
\text { and use of consultants, appointing executives to guide implementation). }\end{array}$ \\
\hline Communication, collaboration and trust & $\begin{array}{l}\text { Information exchange between the company's departments and partners. Common goals and trust relationships } \\
\text { accomplish smooth functioning. }\end{array}$ \\
\hline $\begin{array}{l}\text { Composition of a capable and balanced } \\
\text { project team }\end{array}$ & $\begin{array}{l}\text { When the experience in ERP implementation field doesn't exist, top management comprise a group of people } \\
\text { consisting of external consultants, departments' managers and project leaders in order to monitor the } \\
\text { implementation. This team ensures the efficient implementation and its success, the goals' achievement and the staff } \\
\text { training on ERP system implementation. }\end{array}$ \\
\hline Project management & $\begin{array}{l}\text { Application of knowledge and use of skills, tools, and techniques to project activities to meet the project's } \\
\text { requirements. }\end{array}$ \\
\hline $\begin{array}{l}\text { Business plan, goals, scope, mission \& } \\
\text { vision }\end{array}$ & Provide a clear overview of the desired future situation. \\
\hline Change Management & $\begin{array}{l}\text { It ensures a smooth dealing with the changes which are resulting from BPR. It is supported by top management, } \\
\text { partners and the project team. It depends on the desire and readiness of the company for possible changes. }\end{array}$ \\
\hline Training & $\begin{array}{l}\text { Knowledge delivery to project team members and users. Explanation of the system's logic and practical training. It } \\
\text { aims at the proper understanding of the new business processes and the acquisition of information skills resulting in } \\
\text { the development of various capabilities. }\end{array}$ \\
\hline Business Process Re-engineering (BPR) & $\begin{array}{l}\text { It starts by analyzing the existing work activities. New activities are recording by creating new business processes } \\
\text { according to the system functions. It reduces the system modifications by matching the business processes with the } \\
\text { software. }\end{array}$ \\
\hline Service Quality & Users' support is obtained by external partners (vendors, consultants) and skilled business staff. \\
\hline $\begin{array}{l}\text { IT Infrastructure/Business and IT legacy } \\
\text { systems }\end{array}$ & $\begin{array}{l}\text { IT Infrastructure: Hardware and network existence before the insertion of a new system. Legacy systems: Used } \\
\text { systems before ERP. A source of information about the ERP system's operational activities that helps to address any } \\
\text { problems that may arise during the implementation. }\end{array}$ \\
\hline Users and stakeholders' involvement & It leads to the system's adaptation in users' requirements, the optimum use and users' acceptance. \\
\hline $\begin{array}{l}\text { Software testing, customization and } \\
\text { troubleshooting }\end{array}$ & $\begin{array}{l}\text { Customization of the system is performed in order to maintain specific business processes that create a competitive } \\
\text { advantage in a business. During customization, errors may occur that can be tackled only with the prosecution of } \\
\text { rigorous testing which will contribute to the proper operation of the system. }\end{array}$ \\
\hline Accuracy, Quality \& Data Integrity & $\begin{array}{l}\text { Accurate and reliable data that enters into the system either by legacy information systems or during business } \\
\text { processes and produces correct information. }\end{array}$ \\
\hline System Quality & $\begin{array}{l}\text { It describes how reliable and functional a system is. It is measured by the way it is used, its functionality, flexibility } \\
\text { and accuracy. }\end{array}$ \\
\hline Organizational culture & $\begin{array}{l}\text { The way the business has learned to understand, think and feel. This is communicated by how these features are } \\
\text { shared and channeled among its members. }\end{array}$ \\
\hline ERP package selection & $\begin{array}{l}\text { An ERP system, by its very nature, imposes its own logic on the company's strategy, organization and mentality and } \\
\text { it is imperative that the software package is carefully selected. It depends on business activity and its needs. It is } \\
\text { carried out with the external consultants and vendors. }\end{array}$ \\
\hline $\begin{array}{l}\text { Presence of project champion \& adequate } \\
\text { role }\end{array}$ & $\begin{array}{l}\text { A personality which understands the functions of the system, defines the objectives, assumes the burden of the } \\
\text { project and ensures that its success depends on the involved users. It is often referred to as the project } \\
\text { manager/director. }\end{array}$ \\
\hline $\begin{array}{l}\text { Implementation strategy \& goals } \\
\text { achievement timeframe }\end{array}$ & $\begin{array}{l}\text { Decisions on how to implement an ERP software by using a specific methodology and timeframe. The selection and } \\
\text { the implementation of an ERP system should be the result of a well-thought-out development and application of this } \\
\text { ERP strategy. }\end{array}$ \\
\hline $\begin{array}{l}\text { Performance Monitoring, Evaluation \& } \\
\text { Feedback }\end{array}$ & $\begin{array}{l}\text { The exchange of information between project team members and users. It concerns the measurement of performance } \\
\text { with indicators of users' performance and satisfaction. It is a tactic of measuring progress and controlling efficiency } \\
\text { in terms of use. }\end{array}$ \\
\hline Use of consultants & $\begin{array}{l}\text { Due to the complexity of the system, companies choose to collaborate with consultant companies in order for them } \\
\text { to be helped with the functions of the system. The purpose of consultation is to select the right system, align the } \\
\text { software with the business processes and configure it according to the company's desires. It plays an essential role in } \\
\text { starting the project and is reduced in the last stages of the system's implementation. }\end{array}$ \\
\hline $\begin{array}{l}\text { Users' characteristics, skills and } \\
\text { capabilities }\end{array}$ & Characteristics of users according to their behavior and, especially, their skills \\
\hline $\begin{array}{l}\text { Recognition of qualifications, reward and } \\
\text { motivation }\end{array}$ & ability of a project champion to maintain high morale on system users' by recognizing their achievements. \\
\hline
\end{tabular}




\begin{tabular}{|c|c|}
\hline Minimum customization & $\begin{array}{l}\text { It exists when the company adopts the procedures and functions that are integrated in the ERP software, instead of } \\
\text { seeking to modify it precisely in the company's business processes. It is recommended to avoid the cost of potential } \\
\text { modifications that are unavoidable if they are necessary for the system functionality. It is proposed that the } \\
\text { customization level be set before applying the system. }\end{array}$ \\
\hline Well defined Budget of Project & Creating a detailed and realistic budget before the system's insertion. \\
\hline Post-implementation audit & $\begin{array}{l}\text { It is carried out when the system reaches a growing stage in order to understand whether BPR has a real impact on } \\
\text { the organization or not. It assesses if the goals are being met and provides lessons for the future. }\end{array}$ \\
\hline Realistic expectations & $\begin{array}{l}\text { Presentation of the real needs of a company by eliminating the unrealistic ones during the business plan preparation } \\
\text { and the desired goals' setting. }\end{array}$ \\
\hline Communication plan & A communication policy that channels information between top management, users and external partners. \\
\hline Existence of empowered decision-makers & $\begin{array}{l}\text { Empowering the team to make decisions on time and providing them with implements in order to bring the desired } \\
\text { results during the system implementation. }\end{array}$ \\
\hline $\begin{array}{l}\text { ERP, business \& business processes } \\
\text { alignment }\end{array}$ & $\begin{array}{l}\text { The adaptation of an ERP system with the existing business processes or new ones. Based on this adaptation, the } \\
\text { company managers judg if the company's processes and culture undergo further changes and to what extent. }\end{array}$ \\
\hline National culture & $\begin{array}{l}\text { Bureaucracy, political and legal requirements determine how a business operates and therefore the operation of the } \\
\text { ERP system. }\end{array}$ \\
\hline Competitive \& External Pressures & $\begin{array}{l}\text { Pressure from the external competitive environment affects the company's internal environment. The pressure that } \\
\text { the company receives from the external environment and, at the same time, the creation of innovative and } \\
\text { competitive activities. }\end{array}$ \\
\hline $\begin{array}{l}\text { System support/Maintenance and further } \\
\text { training }\end{array}$ & $\begin{array}{l}\text { It is performed when the system is in the final stage of implementation. The system is supported by maintenance } \\
\text { procedures during which continuous upgrades are made for optimal system operation and additional training that } \\
\text { may be proved necessary. }\end{array}$ \\
\hline ERP vendor selection & $\begin{array}{l}\text { ERP suppliers, creators of system software. They handle the system's installation in the company, provide initial } \\
\text { training and modify the system in collaboration with the consultants. The ERP vendors' selection is based on their } \\
\text { history, support and capabilities. }\end{array}$ \\
\hline Controlled ROI on ERP implementation & An indicator that evaluates the return of investment on ERP. \\
\hline Knowledge Management & $\begin{array}{l}\text { Acquiring the maximum amount of knowledge from external partners and staff in aiming at an automated system } \\
\text { usage. }\end{array}$ \\
\hline Company-Wide Support and Commitment & $\begin{array}{l}\text { Once ERP enters a company, each user is required to adopt the use of the system by participating in the new } \\
\text { responsibilities without invoking the previous working procedures. }\end{array}$ \\
\hline Implemented modules & $\begin{array}{l}\text { The functionality of the system is affected by the number of implemented modules. The company chooses either to } \\
\text { use full range of ERP modules offered or to restrict itself to a specific number of modules according to specific } \\
\text { needs and requirements. }\end{array}$ \\
\hline
\end{tabular}

TABLE V. FREQUENCY ORdER OF THE IDENTIFIED CSFS AFTER THE APPLICATION OF CONTENT ANALYSiS METHOD

\begin{tabular}{|c|c|c|c|}
\hline Id & Factors & Frequency & $(\%)$ \\
\hline 1 & Top management support and commitment & 67 & 6.27 \\
\hline 2 & Communication, collaboration and trust & 66 & 6.17 \\
\hline 3 & Composition of a capable and balanced project team & 65 & 6.08 \\
\hline 4 & Project management & 61 & 5.71 \\
\hline 5 & Business plan, goals, scope, mission and vision & 59 & 5.52 \\
\hline 6 & Training & 55 & 5.14 \\
\hline 7 & Change Management & 54 & 5.05 \\
\hline 8 & Business Process Re-engineering (BPR) & 52 & 4.86 \\
\hline 9 & Users and other stakeholders' involvement in evaluation, modification and implementation of the system & 51 & 4.77 \\
\hline 10 & IT Infrastructure / Appropriate business and IT legacy systems & 51 & 4.77 \\
\hline 11 & Service Quality & 48 & 4.49 \\
\hline 12 & Software testing, customization and troubleshooting & 42 & 3.93 \\
\hline 13 & System Quality & 41 & 3.84 \\
\hline 14 & Accuracy, Quality \& Data Integrity & 37 & 3.46 \\
\hline 15 & Organizational culture & 35 & 3.27 \\
\hline 16 & ERP package selection & 33 & 3.09 \\
\hline 17 & Presence of project champion and adequate role & 32 & 2.99 \\
\hline
\end{tabular}




\begin{tabular}{|c|c|c|c|}
\hline 18 & Implementation strategy and goals achievement timeframe & 32 & 2.99 \\
\hline 19 & Performance Monitoring, Evaluation and Feedback & 28 & 2.62 \\
\hline 20 & Use of consultants & 25 & 2.34 \\
\hline 21 & Users' characteristics, skills and capabilities & 16 & 1.5 \\
\hline 22 & Minimum customization & 16 & 1.5 \\
\hline 23 & Recognition of qualifications, reward and motivation & 15 & 1.4 \\
\hline 24 & Well Defined Project Budget & 13 & 1.22 \\
\hline 25 & Post-implementation audit & 11 & 1.03 \\
\hline 26 & Realistic expectations & 10 & 0.94 \\
\hline 27 & Communication plan & 8 & 0.75 \\
\hline 28 & ERP, business and business processes alignment & 8 & 0.75 \\
\hline 29 & System support / Maintenance and further training & 8 & 075 \\
\hline 30 & Existence of empowered decision-makers & 7 & 0.65 \\
\hline 31 & National culture & 6 & 0.56 \\
\hline 32 & Competitive and External Pressures & 6 & 0.56 \\
\hline 33 & ERP vendor selection & 4 & 0.37 \\
\hline 34 & Controlled ROI on ERP implementation (Return on Investment) & 2 & 0.19 \\
\hline 35 & Knowledge Management & 2 & 0.19 \\
\hline 36 & Company-Wide Support and Commitment & 2 & 0.19 \\
\hline 37 & Implemented modules & 1 & 0.09 \\
\hline \multicolumn{2}{|c|}{ Total } & 1069 & 100 \\
\hline
\end{tabular}

Specifically, the factor of top management commitment and support has the highest number of frequency noting that the right leadership and management are important tools for the success of ERP implementation. The factor of communication, collaboration and trust has the second highest number of frequency which proves that the existence of the above characteristics between business, employees and external partners is crucial for successful ERP implementation. Project team, project management, business plan, change management and users' education factors follow in the order of frequency. These factors are sufficiently referred to as literature, which is something that highlights their importance to the successful implementation. Business Process Re-engineering to system quality factors follow high values in the order of frequency (Id: 41-52), which makes them particularly successful components of ERP implementation. Factors from data accuracy to recognition and reward (Id: 15-37) could very well be considered as the average values of the frequency order. This proves that the literature gives a relative importance to the existence of these factors without giving them the appropriate priority. Factors that range between the last numbers of frequency (Id: 1-13) were not widely reported in the selected material. However, these factors are considered worthy of study and investigation; this could also be a proposal for any further research approach. At this point, the conclusions after applying the content analysis are drawn. The identified critical success factors can be considered individually by the companies in order for the implementation of the system to be successful. Next step is to create categories and classify the identified factors in them in order to draw further conclusions about ERP success.

\section{CRITICAL SUCCESS FACTORS’ CATEGORIZATION}

As it was mentioned in the section of literature review, critical success factors can be classified either into relative categories to the ERP system implementation (or else orientations), into relative categories to the ERP life cycle or in categories related to strategy and tactics $[9,25,27,34$, 38$41,56,59,61,65,81]$. In this analysis, it was decided that critical factors will be classified according to the first two categories and in a combination of them. These types of categorization were chosen due to the fact that they are widely used in the literature. In addition to that, they were selected in order to strengthen the current theoretical framework with perspectives in which CSFs can be taken into account by companies collectively as dimensions of the ERP implementation and its life cycle. At the end of this analysis, the merge of these two categorization forms is held in order to provide further conclusions regarding the successful ERP implementation [53, 76, 95] and, also, to show another way in which CSFs can be taken into account by combining the implementation aspects with those of the system's life stages. Having all the above into consideration, these categories are related to the ERP orientations of implementation and the life stages of the system.

\section{A. First Form of Categorization: ERP Orientations of Implementation}

The first form of categorization concerns the classification of factors into organizational, project, human, technological/ERP and external partners (vendors-consultants) categories [9, 25, 28] (Table VI). 
Once the categories were created, factors were classified according to the selected research material (mentioned in Table III) and the relative literature as indicated in the next table. Thirteen (13) organizational factors, six (6) project factors, five (5) human factors, ten (10) technological/ERP factors and three (3) external partners' related factors arose from the CSFs' classification (Table VII).

TABLE VI. FIRST TYPE OF FACTORS’ CATEgORIZATION

\begin{tabular}{|l|l|l|}
\hline Id & Categories & Conceptual Content of Categories \\
\hline $\mathbf{1}$ & Organizational & $\begin{array}{l}\text { It is related to the company's structure, general } \\
\text { administration, processes, goals, culture, and } \\
\text { business environment }\end{array}$ \\
\hline $\mathbf{2}$ & Project & $\begin{array}{l}\text { It is associated with a group of people who } \\
\text { supervise the ERP project and implementation. }\end{array}$ \\
\hline $\mathbf{3}$ & Human & $\begin{array}{l}\text { It is related to users' relationships with ERP } \\
\text { implementation. Skills and characteristics, } \\
\text { participation and support in ERP implementation } \\
\text { procedures. }\end{array}$ \\
\hline $\mathbf{4}$ & $\begin{array}{l}\text { Technological/ } \\
\text { ERP factors }\end{array}$ & $\begin{array}{l}\text { They are related to the system's functionality and } \\
\text { the technological characteristics. }\end{array}$ \\
\hline $\mathbf{5}$ & $\begin{array}{l}\text { External } \\
\text { partners }\end{array}$ & $\begin{array}{l}\text { They highlight the relationship between company, } \\
\text { ERP system and external partners. }\end{array}$ \\
\hline
\end{tabular}

TABLE VII. CLASSIFICATION OF FACTORS ACCORDING TO THEIR ORIENTATIONS IN ERP IMPLEMENTATION

\begin{tabular}{|c|c|c|}
\hline Categories & Id & Critical Success Factors \\
\hline \multirow{13}{*}{$\begin{array}{l}\text { Organizational } \\
\text { factors }\end{array}$} & 1 & Business Process Re-engineering (BPR) \\
\hline & 2 & Well Defined Budget of Project \\
\hline & 3 & Business plan, goals, scope, mission and vision \\
\hline & 4 & Change Management \\
\hline & 5 & Communication, collaboration and trust \\
\hline & 6 & Communication plan \\
\hline & 7 & Competitive and External Pressures \\
\hline & 8 & Knowledge Management \\
\hline & 9 & National culture \\
\hline & 10 & Organizational culture \\
\hline & 11 & $\begin{array}{l}\text { Controlled ROI on ERP implementation (Return on } \\
\text { Investment) }\end{array}$ \\
\hline & 12 & Realistic expectations \\
\hline & 13 & $\begin{array}{l}\text { Implementation strategy and goals achievement } \\
\text { timeframe }\end{array}$ \\
\hline \multirow{6}{*}{ Project factors } & 1 & Existence of empowered decision-makers \\
\hline & 2 & Performance, Monitoring, Evaluation and Feedback \\
\hline & 3 & Presence of project champion and adequate role \\
\hline & 4 & Project management \\
\hline & 5 & $\begin{array}{l}\text { Composition of a capable and balanced project } \\
\text { team }\end{array}$ \\
\hline & 6 & $\begin{array}{l}\text { Recognition of qualifications, reward and } \\
\text { motivation }\end{array}$ \\
\hline \multirow{3}{*}{ Human factors } & 1 & Top management support and commitment \\
\hline & 2 & Company-Wide Support and Commitment \\
\hline & 3 & Training \\
\hline
\end{tabular}

\begin{tabular}{|l|l|l|}
\hline \multirow{5}{*}{} & 4 & $\begin{array}{l}\text { Users and other stakeholders' involvement in } \\
\text { evaluation, modification and implementation of the } \\
\text { system }\end{array}$ \\
\cline { 2 - 3 } & 5 & Users' characteristics, skills and capabilities \\
\hline \multirow{5}{*}{$\begin{array}{l}\text { Technological/ } \\
\text { ERP factors }\end{array}$} & 1 & Implemented modules \\
\cline { 2 - 3 } & 2 & IT Infrastructure / Business and IT legacy systems \\
\cline { 2 - 3 } & 3 & Software testing, customization and troubleshooting \\
\cline { 2 - 3 } & 4 & System Quality \\
\cline { 2 - 3 } & 7 & Accuracy, Quality \& Data Integrity \\
\cline { 2 - 3 } & 8 & ERP package selection \\
\cline { 2 - 3 } & 9 & ERP, business and business processes alignment \\
\cline { 2 - 3 } & 10 & System support / Maintenance and further training \\
\hline \multirow{4}{*}{$\begin{array}{l}\text { Extertnal } \\
\text { Partners' } \\
\text { factors }\end{array}$} & 1 & Service Quality \\
\hline & 2 & Use of consultants \\
\cline { 2 - 3 } & 3 & ERP vendor selection \\
\hline
\end{tabular}

The differences between the above categories are shown in percentage form below (Fig. 3). It can be noticed that organizational (35\%) and technological/ERP related factors (27\%) outweigh the rest of the other categories. This fact points out that the selected research material, or possibly most of the literature, gives more weight to these dimensions of the implementation. In particular, it is concluded that the successful implementation of ERP systems in various sectors of the economy depends mainly on the components of business management and technological aspects. Under no circumstances do the above comments negate the importance of the other categories - dimensions in the successful implementation of the system.

\section{B. Second Form of Categorization: ERP System's Life Stages}

The second form of categorization involves the classification of factors in the life stages of ERP system [81, $61,59]$. This type of categorization concerns the critical success factors that belong to the pre-implementation phase, implementation phase and the post-implementation phase (Table VIII).

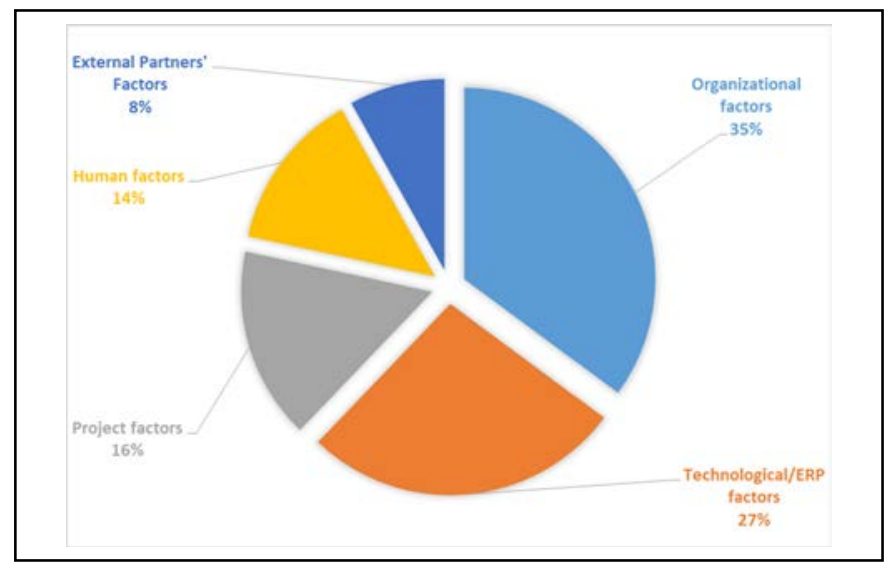

Fig. 3. Deviations' Structure of the First Type of Categorization. 
TABLE VIII. SECOND TYPE OF FACTORS’ CATEGORIZATION

\begin{tabular}{|l|l|l|}
\hline Id & Categories & Conceptual Content of ERP Stages \\
\hline 1 & $\begin{array}{l}\text { Pre- } \\
\text { implementation } \\
\text { phase }\end{array}$ & $\begin{array}{l}\text { Factors related to a company's preparation } \\
\text { procedures for acquiring an ERP system. These } \\
\text { include the system's investment examination, the } \\
\text { software package and external partners' selection } \\
\text { and the strategic planning. }\end{array}$ \\
\hline 2 & $\begin{array}{l}\text { Implementation } \\
\text { phase }\end{array}$ & $\begin{array}{l}\text { Factors related to project-related activities, users' } \\
\text { organization, software testing, configuration, } \\
\text { conversion, stabilization and finally the ERP } \\
\text { implementation. }\end{array}$ \\
\hline 3 & $\begin{array}{l}\text { Post- } \\
\text { implementation } \\
\text { phase }\end{array}$ & $\begin{array}{l}\text { Factors related to activities that take place as long as } \\
\text { the use of the system is in the hands of mature users } \\
\text { and last as long as the processes of upgrading, } \\
\text { maintenance and additional training. At the end of } \\
\text { these processes, the system is replaced with a new } \\
\text { one. }\end{array}$ \\
\hline
\end{tabular}

The use of this type of categorization was made because the ERP success requires the identification and the management of the critical elements in each phase of system life cycle implementation [79]. Once the categories were created, factors were classified, as indicated below according to the selected research material and the relative literature (Table IX).

TABLE IX. FACTORS' CLASSIFICATION ACCORDING TO ERP SYSTEM'S LIFE PHASES

\begin{tabular}{|c|c|c|}
\hline Categories & Id & Critical Success Factors \\
\hline \multirow{19}{*}{$\begin{array}{l}\text { Pre-implementation } \\
\text { phase factors }\end{array}$} & 1 & Top management support and commitment \\
\hline & 2 & Communication, collaboration and trust \\
\hline & 3 & $\begin{array}{l}\text { Composition of a capable and balanced project } \\
\text { team }\end{array}$ \\
\hline & 4 & Business plan, goals, scope, mission and vision \\
\hline & 5 & Change Management \\
\hline & 6 & Business Process Re-engineering (BPR) \\
\hline & 7 & $\begin{array}{l}\text { IT Infrastructure / Business and IT legacy } \\
\text { systems }\end{array}$ \\
\hline & 8 & ERP vendor selection \\
\hline & 9 & Use of consultant \\
\hline & 10 & Implemented modules \\
\hline & 11 & ERP package selection \\
\hline & 12 & Minimum customization \\
\hline & 13 & $\begin{array}{l}\text { Implementation strategy and goals } \\
\text { achievement timeframe }\end{array}$ \\
\hline & 14 & Well Defined Budget of Project \\
\hline & 15 & $\begin{array}{l}\text { Controlled ROI on ERP implementation } \\
\text { (Return on Investment) }\end{array}$ \\
\hline & 16 & Realistic expectations \\
\hline & 17 & Knowledge Management \\
\hline & 18 & National culture \\
\hline & 19 & Competitive and External Pressures \\
\hline \multirow{2}{*}{$\begin{array}{l}\text { Implementation phase } \\
\text { factors }\end{array}$} & 1 & Project management \\
\hline & 2 & Training \\
\hline
\end{tabular}

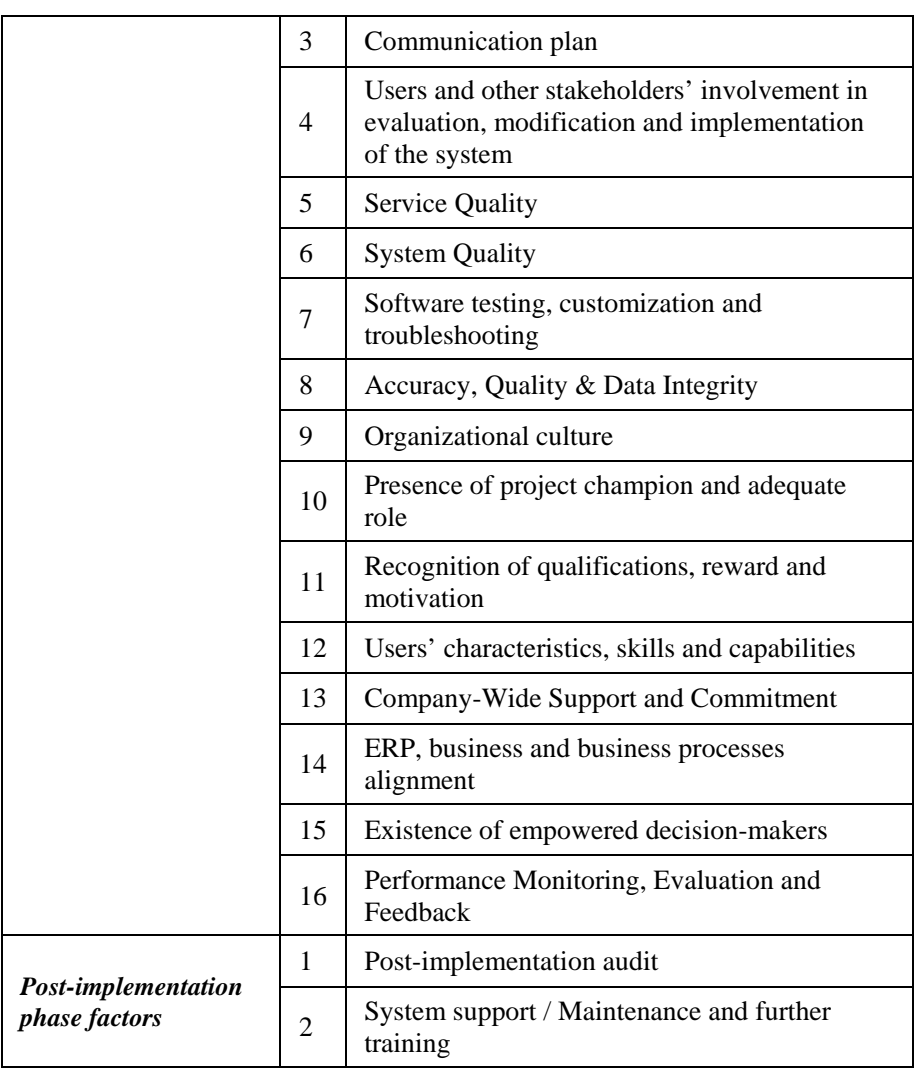

After the CSFs' classification into the above-mentioned categories, nineteen (19) ERP pre-implementation, sixteen (16) ERP implementation and two (2) post-implementation ERP phase factors arise. The differences between the categories are shown in percentage form (Fig. 4) and, as can be seen, ERP pre- implementation and implementation phase factors occupy the largest percentage.

These results point out that the selected research material pays close attention to the first two phases of the system's life. The literature states that in the event that the last phase of system implementation is examined, further factors and parameters should be taken into account, such as the frequency of upgrades, financial support and the provision of specialized assistance by external partners [96, 97].

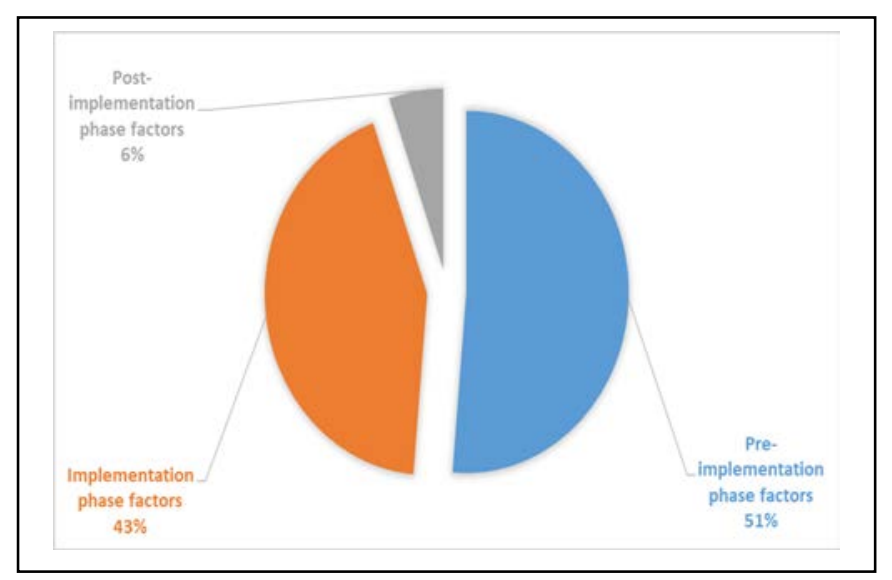

Fig. 4. Deviations' Structure of the Second Type of Categorization. 


\section{Merging of the Two Categorization Forms}

Subsequently, the above types of categorization were merged in order to draw further conclusions about the critical factors, their categorization and the ERP system success [53, 76, 95] (Table X).

The application of the merger shows that eleven organizational, one project, one human, four ERP and two external partners' factors are included in ERP preimplementation phase. Additionally, two organizational, five project, four human, one external partners' and four ERP system factors are taken into account as implementation phase factors also. Finally, two factors relating to the ERP system are entirely post-implementation phase factors. The above results are presented in percentage, cumulative and diagrammatic form below (Table XI, Fig. 5 to 7).

TABLE X. MERGED FACTORS’ CLASSIFICATION

\begin{tabular}{|c|c|c|c|}
\hline Category & Pre-implementation phase factors & Implementation phase factors & Post-implementation phase factors \\
\hline \multirow{11}{*}{ Organizational factors } & Communication, collaboration and trust & \multirow{5}{*}{ Communication plan } & \\
\hline & $\begin{array}{l}\text { Business plan, goals, scope, mission and } \\
\text { vision }\end{array}$ & & \\
\hline & Change Management & & \\
\hline & Business Process Re-engineering (BPR) & & \\
\hline & $\begin{array}{l}\text { Implementation strategy and goals } \\
\text { achievement timeframe }\end{array}$ & & \\
\hline & Well Defined Budget of Project & \multirow{6}{*}{ Organizational culture } & \\
\hline & $\begin{array}{l}\text { Controlled ROI on ERP implementation } \\
\text { (Return on Investment) }\end{array}$ & & \\
\hline & Realistic expectations & & \\
\hline & Knowledge Management & & \\
\hline & National culture & & \\
\hline & Competitive and External Pressures & & \\
\hline Category & Pre-implementation phase factors & Implementation phase factors & Post-implementation phase factors \\
\hline \multirow{5}{*}{ Project factors } & \multirow{5}{*}{$\begin{array}{l}\text { Composition of a capable and balanced } \\
\text { project team }\end{array}$} & Project management & \\
\hline & & $\begin{array}{l}\text { Presence of project champion and adequate } \\
\text { role }\end{array}$ & \\
\hline & & $\begin{array}{l}\text { Recognition of qualifications, reward and } \\
\text { motivation }\end{array}$ & \\
\hline & & Existence of empowered decision-makers & \\
\hline & & $\begin{array}{l}\text { Performance, Monitoring, Evaluation and } \\
\text { Feedback }\end{array}$ & \\
\hline Category & Pre-implementation phase factors & Implementation phase factors & Post-implementation phase factors \\
\hline \multirow{4}{*}{ Human factors } & \multirow{4}{*}{$\begin{array}{l}\text { Top management support and } \\
\text { commitment }\end{array}$} & Training & \\
\hline & & $\begin{array}{l}\text { Users and other stakeholders' involvement in } \\
\text { evaluation, modification and implementation } \\
\text { of the system }\end{array}$ & \\
\hline & & Users’ characteristics, skills and capabilities & \\
\hline & & Company-Wide Support and Commitment & \\
\hline Category & Pre-implementation phase factors & Implementation phase factors & Post-implementation phase factors \\
\hline \multirow{4}{*}{ Technological/ERP factors } & $\begin{array}{l}\text { IT Infrastructure / Business and IT } \\
\text { legacy systems }\end{array}$ & System Quality & \multirow{2}{*}{ Post-implementation audit } \\
\hline & Implemented modules & $\begin{array}{l}\text { Software testing, customization and } \\
\text { troubleshooting }\end{array}$ & \\
\hline & ERP package selection & Accuracy, Quality and Data Integrity & \multirow{2}{*}{$\begin{array}{l}\text { System support / Maintenance and } \\
\text { further training }\end{array}$} \\
\hline & Minimum customization & $\begin{array}{l}\text { ERP, business and business processes } \\
\text { alignment }\end{array}$ & \\
\hline Category & Pre-implementation phase factors & Implementation phase factors & Post-implementation phase factors \\
\hline \multirow{2}{*}{ Extertnal Partners' factors } & ERP vendor selection & \multirow{2}{*}{ Service Quality } & \\
\hline & Use of consultants & & \\
\hline
\end{tabular}


TABLE XI. MERged Factors’ Classification In QuANTITATIVE AND PERCENTAGE Form

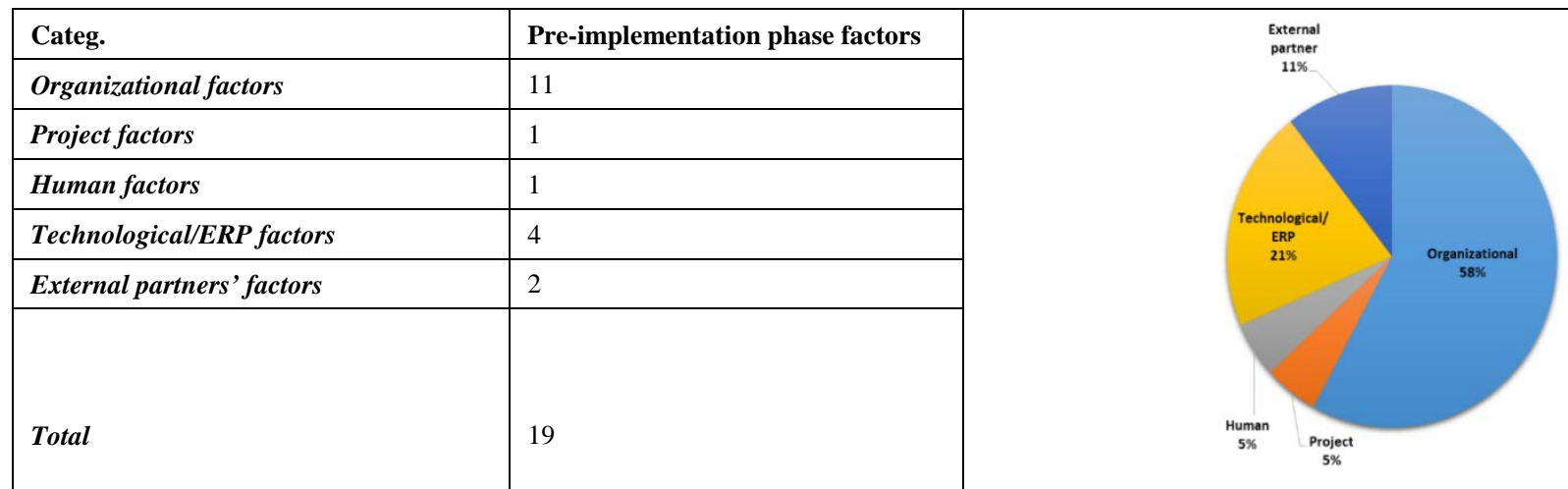

Fig. 5. Pre-Implementation Phase.

\begin{tabular}{|c|c|c|c|}
\hline Categ. & Implementation phase factors & \multirow{6}{*}{$\begin{array}{l}\text { External } \\
\text { parner- } \\
6 \%\end{array}$} & \multirow{2}{*}{$\underset{13 \%}{\text { Organization }}$} \\
\hline Organizational factors & 2 & & \\
\hline Project factors & 5 & & \\
\hline Human factors & 4 & & \\
\hline $\begin{array}{l}\text { Technological/ } \\
\text { ERP factors }\end{array}$ & 4 & & $31 \%$ \\
\hline External partners' factors & 1 & & \\
\hline
\end{tabular}

Total 16

Fig. 6. Implementation Phase.

\begin{tabular}{|l|l|}
\hline Categ. & Post-implementation phase factors \\
\hline Organizational factors & 0 \\
\hline Project factors & 0 \\
\hline Human factors & 0 \\
\hline $\begin{array}{l}\text { Technological/ } \\
\text { ERP factors }\end{array}$ & 2 \\
\hline External partners' factors & 0 \\
\hline & \\
Total & 2 \\
\end{tabular}

Some of the factors, which were categorized into dimensions of the ERP system implementation, have a prominent place both in the pre-implementation and implementation stage while in the last stage the external partners' critical factors gain a dominant role. In particular, the majority of organizational factors seem to play a dominant role in the pre-implementation phase which makes the organizational aspects and further parameters of them necessary elements for the acquisition of the system. Some of these factors, such as communication plan and organizational culture, are included in the second phase emphasizing the importance of their existence during the implementation of the system. On the contrary, the majority of project factors play a greater role in the implementation phase of the system. One of them -the composition of a capable and balanced project teamappears in the pre-implementation phase, noting that its existence prior to system acquisition is essential for the future implementation success. Human factors appear mainly in the implementation phase of the system. Thus, this is something that indicates that the "human" element is particularly presented in activities related to the system implementation flow and the users' administration.

Some of the technological/ERP factors are identified in the pre-implementation phase, which indicates that important decisions must be made by the outset regarding the preexisting situation. These factors are also identified in the 
implementation phase. Therefore, they define guidelines for the system's configuration and quality. It was also concluded that only ERP system factors play a vital role in the postimplementation phase. This is explained by the fact that specific procedures are carried out as soon as the system used matures in the users' hands until it is replaced with a new one. These procedures concern the software maintenance, upgrades, additional user training and implementation audit in order to be made perfectly clear whether the company's goals were accomplished or not. Finally, factors that are relevant to ERP vendors and consultants are superior to the preimplementation phase of the system. This is justified by the fact that in the first stage of ERP implementation, processes that take place in it prepare the company for the acquisition of an ERP system. One of these processes is the selection of external partners, whose quality is evident in the implementation stage, and is an important aspect of the system implementation success.

\section{CONCLUSION}

This study aimed to investigate the critical success factors of enterprise resource planning system implementation and build a categorization framework in order to create a theoretical basis that will enhance any further research approaches in various sectors of the economy. By fulfilling the purpose of this study, a significant contribution to computer science literature and especially to the ERP field is offered. In order for the study's legitimate objective to be achieved, the critical factors of successful ERP implementation were initially determined by reviewing the relevant literature through the use of content analysis method. Then, the identified CSFs were classified into relative categories to the orientations of ERP implementation and ERP system's life cycle phases. Finally, these two types of categorization were merged in order to examine the critical success factors' behavior during the ERP implementation so as for useful conclusions to be drawn.

Content Analysis was chosen because various empirical information systems' studies adopted this method as a part of a research methodology. This method was applied according to the literature's standards in relevant scientific studies which had been found by searching in specific databases and by using keywords about ERP implementation and critical success factors. The studies that were selected to take place in this investigation include the research material that meets the present study's topic requirements. Most of this research material helped in shaping the objective goal of this paper and was considered important for the development of a factors' list that influences the successful ERP implementation in various economic sectors. These sectors were divided into many fields which led to the conclusion that corresponding research applications in these sectors may occur also in the actual range of the literature. CA method was applied by reporting the frequency of CSFs' concept in the selected research material content, something that helped thirty-seven factors to be identified. The conclusions drawn with regard to the frequency results from the application of the content analysis were multiple and presented in detail in the corresponding section above. Specifically, it was generally concluded that the CSFs' reference to the selected research material maybe reflects a real situation of the relevant literature in which emphasis is mainly placed on top management, subsequently on various organizational and financial characteristics highlighting the importance of them in the successful implementation and, finally, on factors that have not been mentioned in detail in the literature, except from some researchers who are considered them worthy of study. The meaning of these factors were also recorded and presented emphasizing, in this way, the success characteristics that should be taken into consideration by entrepreneurs during the ERP system implementation.

After the factors' identification, categories, relative to ERP implementation and its life phases, were created and merged with each other in order to strengthen the theoretical framework towards a more integrated approach for decision making policy regarding the critical factors which influence the ERP implementation success. The first type of categorization referred to the creation of organizational, project, human, technological/ERP and external partners (vendors-consultants) categories and the second one the creation of pre-implementation, implementation and the postimplementation phase categories. The categorization framework was set up by the use of the relevant literature which also suggested the classification of thirty-seven critical factors into the above-mentioned categories. The analysis results showed that the organizational and technological/ERP factors outweigh the rest of the other categories. This proves that the selected research material, or possibly most of the relevant literature, gives more weight to these dimensions of the implementation. In particular, it was concluded that the successful implementation of ERP systems in various sectors of the economy depends mainly on the components of business management and technological aspects, which is something that do not negate the importance of the other dimensions (project, human, external partners) in the successful implementation of the system. It was also pointed out that the selected research material pays close attention to the first two phases of the system's life. Therefore, it was suggested that in the event that the last phase of system implementation is examined, further factors and parameters have to be defined and taken into account directly by the enterprises (frequency of upgrades, financial support and specialized assistance by external partners). Finally, through the application of the merger and the discussion of its results, it is evident in which aspects of ERP implementation emphasis is placed on per system's life cycle phase.

\section{PRACTICAL IMPLICATION AND ORIGINALITY}

By fulfilling the purpose of this study, a significant contribution to computer science literature and especially to the ERP field is offered. Firstly, it is worth mentioning that the discussion of the frequency and categorization results probably helps in understanding the literature's prevailing trends about ERP implementation and CSFs. The discussion on the results that occurred from the merging of the two categorization forms, could very well be referred to as the means with which the aspects that characterize and influence the implementation of ERP system can be taken into account by various companies during the three life stages of the system. Last but not least, it must be pointed out that the 
creation of a theoretical framework, which involves various (four in total) aspects of the treatment of key topics during the ERP implementation, is innovative and constitutes a promising tool that -as it was mentioned earlier in detail- can be used by many researchers as a basis for many types of researches. This study is purely theoretical but, as an available scientific article, may provide background knowledge for conducting a series of further research approaches in specific economic sectors or in a set of them. Present study's authors promise to explicit this knowledge in order to strengthen the computer science literature with new findings.

\section{PROPOSALS FOR FURTHER RESEARCH APPROACHES}

The identification of critical factors through the content analysis application created a theoretical framework which allows critical factors to be considered by companies individually as features of the implementation and the system. According to this perspective, the identification of these factors' importance and influence in the degree of the ERP implementation success is suggested. The importance's ranking of critical factors, specifically, might be a proposal for companies, indicating the order in which the elements of each factor should be taken into account during the ERP implementation. However, further investigation should be carried out in order to include the degree of successful implementation and to study its relationship with critical factors. This type of identification will enable further deepening of the existing literature and disseminate new findings about the ERP system and its implementation in specific economic sectors or in a set of them, such as the above-mentioned general business field. The categorization analysis application respectively led to the creation of three more theoretical frameworks (four in total) that allow critical success factors to be considered by companies not only collectively as dimensions of the ERP implementation and its life phases, but also in combination. According to these perspectives, the identification of these approaches' relationships with the degree of the ERP implementation success is suggested. Through this examination, useful findings can be drawn if the implementation success is shaken positively, negatively or not at all, in the case that critical factors are taken collectively into account by companies as aspects of implementation, life cycle and their possible combination. More specifically, carrying out a corresponding analysis, many researchers will be greatly helped to be aware of the area in which the ERP system implementation may present problems and make various proposals for avoiding the undesirable result.

\section{RESEARCH LiMITATIONS}

One of the most significant limitations of this research was the selection of a literature part to be used for the analysis purposes, given that it was not possible to use the whole literature's studies. Analyzing the relevant literature, many studies conduct a literature review and impose a further investigation by using specially designed questionnaires in order to specify the critical factors that strongly affect the successful ERP system implementation. As mentioned in the introductory section, this study restricts only on the first part, which is something that can be taken into account as a limitation. The existence of this limitation is explained by the fact that this paper aims to create a multilateral theoretical framework that will be used by researchers directly in the part of the further investigation establishment and will further contribute to the ERP literature.

\section{REFERENCES}

[1] E.J. Umble, R.R. Haft and M.M. Umble, "Enterprise resource planning: Implementation procedures and critical success factors". European Journal of Operational Research, Vol. 146, pp. 241-257, 2003.

[2] I.C. Ehie and M. Madsen, "Identifying critical issues in enterprise resource planning (ERP) implementation”. Computers in Industry Vol. 56, pp. 545-557, 2005.

[3] Madapusi and D. Ortiz, "The Influence of Technical Competence Factors in ERP System Implementations". Journal of Applied Business and Economics, Vol. 16, pp. 27-39, 2014.

[4] A. Baykasoglu and I. Gölcük, "Comprehensive fuzzy FMEA model: a case study of ERP implementation risks”. Oper Res Int J,Vol. 20, pp. 795-826, 2020.

[5] P. Chatzoglou, D. Chatzoudes, L. Fragidis and S. Symeonidis, "Critical success factors for ERP implementation in SMEs". Federated Conference on Computer Science and Information Systems, FedCSIS, pp. 1243-1252, 2016.

[6] F. Jalil, A. Zaouia and R. El, "The Impact of the Implementation of the ERP on End-User Satisfaction Case of Moroccan Companies". International Journal of Advanced Computer Science and Applications, Vol. 7, 2016.

[7] H.M. Beheshti, B.K. Blaylock, D.A. Henderson and J.G. Lollar, "Selection and critical success factors in successful ERP implementation”. Competitiveness Review, Vol. 24, pp. 357-375, 2014.

[8] E. Abu-Shanab, R. Abu-Shehab, M. Khairallah, "Critical success factors for ERP implementation: The case of Jordan”. The International Arab Journal of E-Technology, Vol. 4, pp. 1-7, 2015.

[9] N.A.A. Ahmed and M. Sarim, "Critical Success Factors Plays a Vital Role in ERP Implementation in Developing Countries: An Exploratory Study in Pakistan". International Journal of Advanced Computer Science and Applications, Vol. 8, pp. 21-29, 2017.

[10] S. Chaveesuk and S. Hongsuan, "A Structural Equation Model of ERP Implementation Success in Thailand". Review of Integrative Business and Economics Research, Vol. 6, pp. 194-204, 2017.

[11] M.I. Mahraz, L. Benabbou and A. Berrado, "Implementation and Management of ERP Systems: A Literature Review”. International Conference on Industrial Engineering and Operations Management Bandung, Indonesia, IEOM Society International, pp.1684-1694, 2018.

[12] S. Santos, C. Santana and J. Elihimas, "Critical Success Factors For ERP Implementation In Sector Public: An Analysis Based on Literature and a Real Case". Twenty-Sixth European Conference on Information Systems (ECIS) proceedings, Portsmouth, UK, pp.01-15, 2018.

[13] S.E. Hamdi and A. Abouabdella, "Literature review of implementation of an enterprise resources planning: Dimensional approach". 4th International Conference on Logistics Operations Management (GOL), Le Havre, France, IEEE, pp. 01-07, 2018.

[14] S. Alkatheri, and S. Almandeel, S. "An Exploration of Critical Success Factors for Enterprise Resource Planning System Implementation”. The International Journal of Humanities and Social Studies, Vol. 7, pp. 1018, 2019.

[15] M.S. Shakkah, K. Alaqeel, A. Alfageeh and R. Budiarto, "An Investigation Study on Optimizing Enterprise Resource Planning (ERP) Implementation in Emerging Public University: Al Baha University Case Study". International Journal of Electrical and Computer Engineering (IJECE), Vol. 6, pp. 1920-1928, 2016.

[16] N. Karia and M. Soliman, "Factors affecting enterprise resource planning (ERP) systems adoption among higher education institutions in Egypt”. International Journal of Advanced and Applied Sciences, Vol. 4, pp. 144-151, 2017.

[17] M. Haddara, "ERP systems selection in multinational enterprises: a practical guide". International Journal of Information Systems and Project Management, Vol. 6, pp. 43-57, 2018. 
[18] Z. Yajun, L. Yujie and M. Skibniewski, "Enterprise Resource Planning Systems for Project Based Firms: Benefits, Costs \& Implementation Challenges". Journal for the Advancement of Performance Information and Value (PBSRG), Vol. 4, pp. 85-96, 2012.

[19] A. Wibowo and M.W. Sari, "Measuring Enterprise Resource Planning (ERP) Systems Effectiveness in Indonesia”. TELKOMNIKA (Telecommunication Computing Electronics and Control), Vol. 16, pp. 343-351, 2018.

[20] E. Reitsma and P. Hilletofth, "Critical success factors for ERP system implementation: a user perspective”. European Business Review, Vol. 30, pp. 285-310, 2018.

[21] S. Duangekanong, "Factors Influencing the Success of an ERP System: A Study in the Context of an Agricultural Enterprise in Thailand". Silpakorn U Science \& Tech J, Vol. 8, pp. 18-45, 2014.

[22] Panorama Consulting Solutions, "2018 ERP report a Panorama Consulting Solutions research report”. Panorama Consulting Solutions, 2018.https://cdn2.hubspot.net/hubfs/2184246/2018\%20ERP\%20Report. pdf. Assesed 10/6/2018.

[23] Panorama Consulting Solutions. "2017 ERP report a Panorama Consulting Solutions research report”. Panorama Consulting Solutions, 2017. content/uploads/2017/07/2017-ERP-Report.pdf. Assesed 10/6/2018.

[24] A. Fadelelmoula, "The effects of the critical success factors for ERP implementation on the comprehensive achievement of the crucial roles of information systems in the higher education sector". Interdisciplinary Journal of Information, Knowledge, and Management, Vol. 13, pp. 2144, 2018.

[25] S. Dezdar and A. Sulaiman, "Successful enterprise resource planning implementation: taxonomy of critical factors". Industrial Management and Data Systems, Vol.109 No.8, pp.1037-1052, 2009.

[26] A. Tarhini, H. Ammar, T. Tarhini and R. Masa'deh, "Analysis of the Critical Success Factors for Enterprise Resource Planning Implementation from Stakeholders' Perspective: A Systematic Review”. International Business Research, Vol. 8, pp. 25-40, 2016.

[27] J. Ram and D. Corkindale, "How "critical" are the critical success factors (CSFs)? Examining the role of CSFs for ERP”. Business Process Management Journal, Vol. 20, pp. 151-174, 2014.

[28] F.C.F. Leandro, M.P. Méxas and G.M. Drumond, "Identifying critical success factors for the implementation of enterprise resource planning systems in public educational institutions". Brazilian Journal of Operations and Production Management, Vol. 14, pp. 529-541, 2017.

[29] M. Al-Mashari, A. Al-Mudimigh and M. Zairi, "Enterprise resource planning: a taxonomy of critical factors". European Journal of Operational Research, Vol. 146, pp. 352-364, 2003.

[30] S.Y. Huang, A. Chiu, P.C. Chao and A. Arniati, "Critical Success Factors in Implementing Enterprise Resource Planning Systems for Sustainable Corporations”. Sustainability, Vol. 11, pp. 1-53, 2019.

[31] E. Hustad and D. Olsen, "ERP Implementation in an SME: A Failure Case”, in: J. Devos, H. van Landeghem and D. Deschoolmeester (ed) Information Systems for Small and Medium-sized Enterprises. Progress in IS. Berlin, Heidelberg: Springer, 2014.

[32] M.M. Ahmad, and R.P. Cuenca, "Critical success factors for ERP implementation in SMEs". Robotics and Computer-Integrated Manufacturing, Vol.29, pp. 104-111, 2013.

[33] E.W.T. Ngai, C.C.H. Law and F.K.T Wat, "Examining the critical success factors in the adoption of enterprise resource planning". Computers in Industry, Vol. 59, pp. 548-564, 2008.

[34] R. Farrokhian, F. Soleimani, Y. Gholipour-Kanani and S. Ziabari, “A Structural Equation Model for Identifying Critical Success Factors of Implementing ERP in Iranian, Kalleh Food Product Company”. In the 2014 International Conference on Industrial Engineering and Operations Management Bali, Indonesia, 2014.

[35] F.F.H. Nah, J.L.S Lau and J. Kuang, "Critical factors for successful implementation of enterprise systems". Business Process Management Journal, Vol. 7, pp. 285-296, 2001.

[36] F.F.H. Nah and S. Delgado, "Critical success factors for enterprise resource planning implementation and upgrade". Journal of Computer Information Systems 47:99-113, 2006.
[37] R. Thompson, O. Olugbara and A. Singh, "Deriving critical success factors for implementation of enterprise resource planning systems in higher education institution". The African Journal of Information Systems, Vol. 10, pp. 21-47, 2018.

[38] Z. Zhang, M.K.O Lee, P. Huang, L. Zhang and X. Huang, "A framework of ERP systems implementation success in China: An empirical study”. International Journal of Production Economics, Vol. 98, pp. 56-80, 2005.

[39] S. Finney and M. Corbett M, "ERP implementation: a compilation and analysis of critical success factors”. Business Process Management Journal, Vol. 13, pp. 329-347, 2007.

[40] P. Holland and B. Light. "A Critical Success Factors Model For Enterprise Resource Planning Implementation|. Seventh European Conference on Information Systems (ECIS), Copenhagen, IEEE Software, pp.30-36, 1999.

[41] L. Zhang, M.K.O. Lee, Z. Zhang and P. Probir Banerjee, "Critical Success Factors of Enterprise Resource Planning Systems Implementation Success in China”. 36th Hawaii International Conference on System Sciences (HICSS), Big Island, HI, USA, IEEE, pp. 01-10, 2002.

[42] S. Lakshmanan, S. Edmund and D. Kinslin, "An Empirical Analysis on Critical Success Factors for Enterprise Resource Planning (ERP) Implementation in Automobile Auxiliary Industries:. International Journal of Engineering \& Technology, Vol. 7, pp. 447-452, 2018.

[43] M.M. Nkasu, "Investigation of the Effects of Critical Success Factors on Enterprise Resource Planning (ERP) Systems Implementation in the United Arab Emirates”, in S. Satapathy, V. Bhateja, J. Mohanty and S. Udgata (ed) Smart Intelligent Computing and Applications. Smart Innovation, Systems and Technologies, vol 159. Signapore: Springer, 2020.

[44] N. Ahmad, A. Haleem and A.A. Syed, "Compilation of Critical Success Factors in Implementation of Enterprise Systems: A Study on Indian Organizations”. Global Journal of Flexible Systems Management, Vol. 13, pp. 217-232, 2012.

[45] D. Silverman, "Doing Qualitative Research: A Practical Handbook", Thousand Oaks, CA: Sage, 2000.

[46] M. Nasir and S. Sahibuddin, "Critical success factors for software projects: A comparative study”. Scientific Research and Essays, Vol. 6, pp. 2174-2186, 2011.

[47] H.F. Hsieh and S.E. Shannon, "Three Approaches to Qualitative Content Analysis”. Qualitative Health Research, Vol. 15, pp. 1277-1288, 2005.

[48] E.R. Babbie, The Practice of Social Research, 12th ed., Belmont: Wadsworth, Cengage Learning, 2010.

[49] A.B. Marvasti, "Qualitative content analysis: A novice’s perspective”. Forum Qualitative Sozialforschung, 2019.

[50] Strauss and J.M. Corbin, "Basics of qualitative research: Grounded theory procedures and techniques”. Sage Publications, Inc, 1990.

[51] K. Carley, "Coding Choices for Textual Analysis: A Comparison of Content Analysis and Map Analysis”. Sociological Methodology, Vol. 23, pp. 75-126, 1993.

[52] M. Hassan, M.A. Jabar, F. Sidi,Y.Y. Jusoh and S. Abdullah, "Critical Success Factors and their Influence in ERP implementation success of Organizational Performance”. Acta Informatica Malaysia (AIM), Vol. 2, pp. 12-16, 2018.

[53] J. Esteves and J. Pastor, "Towards the unification of critical success factors for ERP implementations". 10th Annual BIT Conference, Manchester, UK, 2000.

[54] B. Wong and D. Tein, "Critical Success Factors for ERP Projects". Australian Institute of Project Management Conference Program, AIPM, Sydney, pp. $01-08,2003$.

[55] A. Shatat, "Critical Success Factors in Enterprise Resource Planning (ERP) System Implementation: An Exploratory Study in Oman". The Electronic Journal of Information Systems Evaluation, Vol. 18, pp. 3645, 2015.

[56] A.U. Shedu and T. Masunda, "The review of critical success factors of enterprise resource planning system implementation". Discovery Publications, Vol. 54, pp. 484-495, 2018. 
[57] B. Gartner and C. Duller, "Critical Factors of ERP System Implementation - Quantitative Empirical Results from Austria”. International Journal of Strategic Management, Vol. 17, pp. 69-88, 2017.

[58] B.C. Villari and S. Jharkharia, "Critical Success Factors for ERP Implementation: A Classification”. Twelfth AIMS International Conference on Management, Kozhikode, Kerala, India, pp. 1013-1022, 2014.

[59] J. Desalegn and A. Petterson, "Investigation of Critical success factors for ERP implementation: A user perspective”. Dissertation, Jonkoping University, 2018.

[60] E. Reitsma, P. Hilletofth and U. Mukhtar, "Enterprise Resource Planning System Implementation: a User Perspective”. Operations and Supply Chain Management, Vol. 11, pp. 110-117, 2018.

[61] J. Motwani, R. Subramanian and P. Gopalakrishna, "Critical factors for successful ERP implementation: Exploratory findings from four case studies”. Computers in Industry, Vol. 56, pp. 529-544, 2005.

[62] J. Ram, D. Corkindale and M. Wu, "Implementation critical success factors (CSFs) for ERP: Do they contribute to implementation success and post-implementation performance". Int. J. Production Economics, Vol. 144, pp. 157-174, 2013.

[63] J. Wu, "Critical Success Factors for ERP System Implementation”, in L.D. Xu, A.M. Tjoa and S.S. Chaudhry (ed) Research and Practical Issues of Enterprise Information Systems II. The International Federation for Information Processing. Boston: Springer, pp. 739-745, 2007.

[64] K. Al-Fawaz, Z. Al-Salti and T. Eldabi, "Critical success factors in ERP implementation: A review”. European and Mediterranean Conference on Information Systems, EMCIS 2008, Brunel University, Uxbridge, United Kingdom, pp.1-9, 2008.

[65] K. Elmeziane, S. Chuanmin and M. Elmeziane, "The Importance of Critical Success Factors of Enterprise Resources Planning Implementation In China”. Business Management Dynamics, 2011.

[66] M. Moohebat, A. Asemi and M.D. Jazi, "A Comparative Study of Critical Success Factors (CSFs) in Implementation of ERP in Developed and Developing Countries”. International Journal of Advancements in Computing Technology, Vol. 2, pp. 99-110, 2010.

[67] M. Saleh, M. Abbad and M. Al-Shehri, "ERP Implementation Success Factors in Saudi Arabia". International Journal of Computer Science and Security (IJCSS) 7:15-30, 2013.

[68] O. Francoise, M. Bourgault and R. Pellerin, "ERP implementation through critical success factors' management”. Business Process Management Journal, Vol. 15, pp. 371-394, 2009.

[69] P. Chatzoglou, D. Chatzoudes and G. Apostolopoulou, "Examining the Antecedents and Outcomes of ERP Implementation Success: An Explanatory Study”, in E. Ziemba (Ed.): AITM 2016/ISM 2016, LNBIP 277, 2017, Springer International Publishing AG, pp. 157-178, 2017.

[70] S. Dezdar and A. Sulaiman, "Critical Success Factors for Erp Implementation: Insights from a Middle-Eastern Country”. Middle-East Journal of Scientific Research. Vol. 10, pp. 798-808, 2011.

[71] S.M. Jafari, M.R. Osman, R.M. Yusuff and S.H. Tang, "Erp systems implementation in Malaysia: The importance of critical success factors". International Journal of Engineering and Technology, Vol. 3, pp. 125131, 2006.

[72] T.R. Bhatti, "Critical Success Factors for the Implementation of Enterprise Resource Planning (ERP): Empirical Validation”. Second International Conference on Innovation in Information Technology (IIT’05), Dubai, India, UAE, pp.1-10, 2005.

[73] A. Gandhi, "Critical Success Factors in ERP Implementation and their interrelationship using TISM and MICMAC Analysi”. Indian Journal of Science and Technology, Vol. 8, pp. 138-150, 2015.

[74] A. Gianopoulos, "Critical Success Factors in ERP Systems Implementation: the case of medium and small sized Enterprises". Journal of Business Management and Applied Economics, Vol. 4, pp. 01-16, 2015.

[75] C. Doom, K. Milis, S. Poelmans and E. Bloemen, "Critical success factors for ERP implementations in Belgian SMEs". Journal of Enterprise Information Management, Vol. 23, pp. 378-406, 2010.
[76] C. Leyh, "Critical Success Factors for ERP Projects in Small and Medium-sized Enterprises - The Perspective of Selected German SMEs". Federated Conference on Computer Science and Information Systems, Warsaw, Poland, IEEE, pp.1181-1190, 2014.

[77] C.L. Gurudatt, B. Ravishankar and R.V. Jayathirtha, "Gross Deviation Analysis (GDA) of delay as a tool for effective ERP implementation in Indian SMEs, Industrial Engineering Journal, Vol. 7, pp. 1-14, 2014.

[78] L. Ganesh and A. Mehta, A "Critical success factors for successful enterprise resource planning implementation at Indian SMEs". International Journal of Business, Management and Social Sciences, Vol. 1, pp. 65-78, 2010.

[79] T.C. Loh and S.C.L Koh, "Critical elements for a successful enterprise resource planning implementation in small- and medium-sized enterprises”. International Journal of Production Research, Vol. 42, pp. 3433-3455, 2004.

[80] V. Hasheela-Mufeti and K. Smolander, "What are the requirements of a successful ERP implementation in SMEs? Special focus on Southern Africa". International Journal of Information Systems and Project Management,Vol. 5, pp. 5-20, 2017.

[81] A.Y. Akbulut and J. Motwani, "Critical Factors in the Implementation and Success of Enterprise Resource Planning (ERP)”. Seidman Business Review, Vol. 11, pp. 20-23, 2005.

[82] H.S. Woo, "Critical success factors for implementing ERP: the case of a Chinese electronics manufacturer". Journal of Manufacturing Technology Management, Vol. 18, pp. 431-442, 2007.

[83] I. Zouaghi and A. Laghouag, "Aligning Key Success Factors to ERP Implementation Strategy: Learning from a Case Study". 4th International Conference on Information Systems, Logistics and Supply Chain, Creative Logistics for an uncertain world, Quebec (Canada), 2012.

[84] S. Khan and M. Anwar, "Analysis of Critical Success Factors (CSFs) for Implementation of Enterprise Resource Planning (ERP) in Manufacturing Industry”. International Journal of Scientific and Engineering Research, Vol. 10, pp: 392-402, 2019.

[85] Y. Lin, M. Lee, H.P. Tserng, "Construction Enterprise Resource Planning Implementation: Critical Success Factors - Lesson Learning in Taiwan”. 20th ISARC, Eindhoven, Holland, I.A.A.R.C, pp.623-628, 2003.

[86] A.I. ALdayel, M.S. ALdayel and A.S. Al-Mudimigh, "The Critical Success Factors of ERP implementation in Higher Education in Saudi Arabia: A Case Study". Journal of Information Technology and Economic Development, Vol. 2, pp. 1-16, 2011.

[87] M.A. Al-Hadi and N.A. Al-Shaibany, "Critical Success Factors (CSFs) of ERP in Higher Education Institutions". International Journal of Advanced Research in Computer Science and Software Engineering, Vol. 7, pp. 92-95, 2017.

[88] J. Arvidsson and D. Kojic, "Critical Success Factors in ERP Implementation: The Perspective of the Procurement System User". Dissertation, Jonkoping University, 2017.

[89] V. Yildirim and A. O. Kusakci, "The Critical Success Factors Of Erp Selection And Implementation: A Case Study In Logistics Sector". Journal of International Trade, Logistics and Law, Vol. 4, pp. 138-146, 2018.

[90] A.A. Mengistie, P. Heaton and M. Rainforth, "Analysis of the Critical Success Factors for ERP Systems Implementation in U.S. Federal Offices". Innovation and Future of Enterprise Information Systems, Lecture Notes in Information Systems and Organisation. Berlin, Heidelberg: Springer, 2013.

[91] S. Rahayu and V.J. Dillack, "Key Success Factor for Successful ERP Implementation in State Owned Enterprises". International Journal of Engineering \& Technology, Vol. 7, pp. 916-919, 2018.

[92] P. Garg, "Critical Success factors for Enterprise Resource Planning implementation in Indian Retail Industry: An Exploratory study". International Journal of Computer Science and Information Security (IJCSIS), Vol. 8, pp. 01-06, 2010.

[93] M. Agaoglu, E.S. Yurtkoru, A. Ekmekçi, "The effect of ERP implementation CSFs on business performance: an empirical study on users' perception”. International Conference on Leadership, 
Technology, Innovation and Business Management, Elsevier Ltd, pp. 35 $-42,2015$.

[94] M. Pourjabbar and M. Delgir, "Critical Success Factors (CSF) for Enterprise Resource Planning (ERP) in Financial Institutes (Case Study: Bank Saderat Iran)”. Int. J. of Comp. \& Info. Tech. (IJOCIT), Vol. 5, pp. 77-88, 2018.

[95] Z. Saadat and A. Afsharnejad, "Critical Success Factors in Implementation of Enterprise Resource Planning Systems: A Case of Golrang Company in Iran”. IOSR Journal of Business and Management (IOSR-JBM), Vol. 18, pp. 32-37, 2016.
[96] D.L. Olson, and F. Zhao, "International Federation for Information Processing”, in A.M. Tjoa, L. Xu and S. Chaudhry (ed), Research and Practical Issues of Enterprise Information Systems, Boston: Springer, pp. 569-578, 2006.

[97] C. Barth and S. Koch, "Critical success factors in ERP upgrade projects”. Industrial Management and Data Systems, Vol. 119, pp. 656676, 2019. 